\title{
Tomato genotype resistance to whitefly mediated by allelochemicals and $\mathrm{Mi}$ gene
}

\author{
Irã Pinheiro Neiva ${ }^{1 *}$, Alex Antônio da Silva ${ }^{2}$, Jéssica Figueiredo Resende ${ }^{2}$, Regis de Castro Carvalho ${ }^{2}$, \\ Alisson Marcel Souza de Oliveira ${ }^{2}$, and Wilson Roberto Maluf ${ }^{2}$ \\ 'Instituto Federal de Educação Ciência e Tecnologia do Norte de Minas Gerais (IFNMG), Rodovia BR 367, km 278, Araçuaí, Minas
Gerais, Brasil. *Corresponding author (iraagronomia@ yahoo.com.br).
${ }^{2}$ Universidade Federal de Lavras (UFLA), Campus Universitário, Lavras, Minas Gerais, 37200-000, Brasil.
}

Received: 18 July 2018; Accepted: 16 November 2018; doi:10.4067/S0718-58392019000100124

\begin{abstract}
Allelochemicals and $M i$, nematode-resistant gene, are found in wild tomato species and can provide resistance to insect pests. The aim of this study was to check the resistance of tomato (Solanum lycopersicum L.) genotypes with different foliar allelochemical contents (acylsugar and/or zingiberene) associated with and not associated with the Mi gene against the whitefly (Bemisia tabaci biotype B). Fifteen tomato genotypes were tested for resistance against whitefly (Santa Clara, TOM-695, TOM-556, TOM-584, TOM-684, TOM-687, TOM-688, TOM-759, TOM-760, ZGB-703, ZGB-704, TOM-778, TOM-779, TOM-780, and PI-127826). Genotypes with high acylsugar (AS) (TOM-687 and TOM-688) as well as those with high zingiberene (ZGB) contents (ZGB-703 and ZGB-704) had lower oviposition and a lower number of nymphs when compared with genotypes with low AS and ZGB contents and without the Mi gene (Santa Clara, TOM695, TOM-556, and TOM-584). The genotypes carrying the Mi gene, associated with low allelochemical contents, were less preferred for whitefly oviposition compared with susceptible genotypes with low AS and ZGB contents and without the Mi gene. When both the AS and ZGB allelochemicals were present in the same genotypes (TOM-778, TOM-779, and TOM-780), they showed a synergistic effect; the number of whitefly eggs and nymphs decreased in genotypes with high AS and ZGB compared with genotypes that had only one of these allelochemicals. However, the number of whitefly eggs and nymphs of genotypes with high AS and ZGB contents, individually or combined, was less than for genotypes carrying the $M i$ gene. These results indicate that allelochemicals are more effective than the $M i$ gene to provide resistance to whitefly.
\end{abstract}

Key words: Bemisia tabaci, plant breeding, secondary substances, Solanum lycopersicum.

\section{INTRODUCTION}

Tomato (Solanum lycopersicum L.) is widely cultivated in the tropical and subtropical regions of the world. Brazil is the eighth largest tomato producer worldwide, and the occurrence of phytosanitary problems is a limiting factor for its production (Toloy et al., 2018). Among the most frequent pests, the whitefly (Bemisia tabaci biotype B and $B$. argentifolii Bellows \& Perring [Hemiptera: Aleyrodidae]) is considered as an important insect pest; it causes direct damage due to loss of the photosynthetically active area, and leads to yield losses (Desneux et al., 2011). It also causes indirect damage because it is a Geminivirus virus vector, which is responsible for irreversible physiological disorders (Inoue-Nagata et al., 2016).

Pesticides are mostly used for pest control in tomato. Insecticides are systematically applied by spraying, generally two or three applications a week in the warmer seasons. Several problems can occur such as residue accumulation in fruits, worker poisoning, environmental pollution, and increased production costs (Silva et al., 2009; 2013). 
The development of pest- and arthropod-resistant genotypes through crop breeding programs is a viable alternative to solve problems arising from the indiscriminate use of agrochemicals. Programs developed in Brazil have pursued the introgression strategy of insect-resistant alleles, which are present in wild tomato species and elite inbred lines (Silva et al., 2013; Andrade et al., 2017; Vosmam et al., 2018). Pest resistance in these wild species is mediated by allelochemicals, which are generally associated with glandular foliar trichomes (Resende et al., 2006; Maluf et al., 2007; Andrade et al., 2018; Silva et al., 2018).

Tomato genotypes with high allelochemical levels were obtained from controlled interspecific hybridization between cultivated tomato and wild species. For example, S. pennellii Correll produce the acylsugar (AS) allelochemical (Resende et al., 2006) and S. habrochaites S. Knapp \& D.M. Spooner var. hirsutum produces zingiberene (ZGB), a sesquiterpene hydrocarbon (Maluf et al., 2001; Freitas et al., 2002). These allelochemicals provide resistance to whitefly (B. tabaci biotype B) (Hemiptera: Aleyrodidae) (Resende et al., 2009; Silva et al., 2009; Maluf et al., 2010; Neiva et al., 2013, Andrade et al., 2017), South American tomato pinworm (Tuta absoluta) (Lepidoptera: Gelechiidae) (Goncalves Neto et al., 2010; Oliveira et al., 2012), mites (Tetranychus urticae and T. evansi) (Acari: Tetranychidae) (Maluf et al., 2007), leafminer (Liriomyza trifolii) (Silva et al., 2018), and aphid (Myzus persicae) (Silva et al., 2013).

The Mi gene produces resistance to nematodes Meloidogyne spp. in tomato (Smith, 1994). Furthermore, the effectiveness of this gene to provide resistance to other pests has also been reported. Kaloshian et al. (1995) and Rossi et al. (1998) reported tomato resistance to aphid Macrosiphum euphorbiae (Thomas) (Hemiptera: Aphididae) associated with the presence of the $M i$ gene. Nombela et al. (2003) and Rodríguez-Álvarez et al. (2017) found that the Mi-1.2 gene, or another gene linked to it, gives resistance to B. tabaci in tomato genotypes (S. lycopersicum). Resistance to B. tabaci in tomato mediated by the $\mathrm{Mi}$ gene, or another gene linked to it, was also observed, and the influence of AS content was tested. However, there are no reports comparing resistance levels against whitefly in tomatoes bearing ZGB associated with AS and the Mi gene.

The aim of this study was to quantify the resistance to whitefly (B. tabaci biotype B) of tomato genotypes with different foliar allelochemical contents (AS and/or ZGB) associated or not associated with the Mi gene.

\section{MATERIALS AND METHODS}

The experiment was carried out in a greenhouse at the Horticultural Experimental Station-HortiAgroSementes Ltda.,

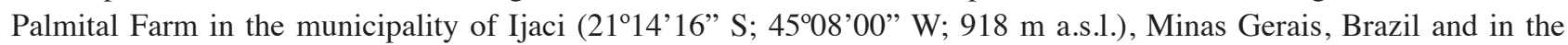
Horticulture Sector of the Universidade Federal de Lavras (UFLA) in the municipality of Lavras (21 ${ }^{\circ} 14^{\prime} 43^{\prime \prime}$ S; $45^{\circ} 59^{\prime} 59^{\prime \prime}$ W; 918 m a.s.l.), Minas Gerais, Brazil.

Fifteen tomato genotypes belonging to the tomato breeding program of the UFLA, which exhibited different AS, ZGB, and $M i$ gene levels were evaluated (Table 1). The Santa Clara, TOM-695, TOM-556, and TOM-584 inbred lines were used as susceptible controls, whereas the S. habrochaites var. hirsutum PI-127826 accession was used as the resistant control.

All 15 tomato genotypes were previously selected. Genotypes with high AS and ZGB foliar contents were selected based on their concentration in the leaflets by the colorimetric method proposed by Freitas et al. (2002) and Resende et al. (2006). Genotypes bearing the $M i$ allele were selected in nematode resistance assays.

Seeds of all genotypes were sown in polystyrene trays with 128 cells and containing commercial substrate (Tropstrato HA Hortaliças, Vida Verde, Mogi Mirim, São Paulo, Brazil). Afterward, plants were transplanted $40 \mathrm{~d}$ after sowing in plastic pots $(500 \mathrm{~mL})$ containing a mixture of soil, commercial substrate, sand, lime, and NPK.

For B. tabaci biotype B infestation, whitefly rearing was established in the Horticulture Sector of the UFLA in a $12 \mathrm{~m}^{2}$ greenhouse; the chapel type protective structure $(4 \mathrm{~m} \times 3 \mathrm{~m})$ consisted of $100 \mu$ thick clear plastic cover and anti-aphid netting on the sides. Adult insects were collected in 'Santa Clara' tomato plants and then transferred to a screened greenhouse. Approximately 50 'Santa Clara' plants (which showed low ZGB and AS contents and susceptibility to whitefly) were used for oviposition and feeding the insects. These plants were also used as an infestation source and kept in the greenhouse during the experiment.

All 15 genotypes were transported $24 \mathrm{~d}$ after transplanting to another greenhouse with anti-aphid netting previously infested with B. tabaci biotype B; this greenhouse was also located in the Horticulture Sector of the UFLA. The experiment was established in the greenhouse with a completely randomized design (CRD), one plant per pot, and six replicates for each of the 15 treatments. 
Table 1. Description of evaluated tomato genotypes, mean number of eggs and nymphs on $2 \mathrm{~cm}^{2}$ leaf area measured at 6 and $20 \mathrm{~d}$, respectively, after Bemisia tabaci biotype B infestation in the upper third of tomato plants.

\begin{tabular}{|c|c|c|c|c|c|c|}
\hline \multirow[b]{2}{*}{ Genotypes $^{(a)}$} & \multicolumn{2}{|c|}{ Foliar content } & \multirow[b]{2}{*}{$M i-1$ gene } & \multirow[b]{2}{*}{ Reference } & \multirow{2}{*}{$\begin{array}{l}\text { Mean number of } \\
\text { eggs } 2 \mathrm{~cm}^{2} \text { leaflet }\end{array}$} & \multirow{2}{*}{$\begin{array}{c}\text { Mean number of } \\
\text { nymphs } 2 \mathrm{~cm}^{2} \text { leaflet }\end{array}$} \\
\hline & Acylsugar & Zingiberene & & & & \\
\hline T1 Santa Clara & Low & Low & No & Silva et al. (2008) & $63.12 \mathrm{~h}$ & $94.25 \mathrm{i}$ \\
\hline T2 TOM-695 & Low & Low & No & Nizio et al. (2008) & $51.21 \mathrm{~g}$ & $81.62 \mathrm{~h}$ \\
\hline T3 TOM-556 & Low & Low & No & Resende et al. (2006) & $52.21 \mathrm{~g}$ & $79.71 \mathrm{~h}$ \\
\hline T4 TOM-584 & Low & Low & No & Resende et al. (2006) & $50.96 \mathrm{~g}$ & $80.83 \mathrm{~h}$ \\
\hline T5 TOM-684 & Low & Low & Yes & Resende et al. (2006) & $43.33 \mathrm{f}$ & $69.58 \mathrm{~g}$ \\
\hline T6 TOM-687 & High & Low & No & Personal communication & $31.08 \mathrm{e}$ & $55.67 \mathrm{f}$ \\
\hline T7 TOM-688 & High & Low & No & Pereira et al. (2008) & $28.42 d$ & $55.75 f$ \\
\hline T8 TOM-759 & High & Low & Yes & Pereira et al. (2008) & $23.50 \mathrm{c}$ & $50.50 \mathrm{c}$ \\
\hline Т9 ТОМ-760 & High & Low & Yes & Personal communication & $24.42 \mathrm{c}$ & $52.38 \mathrm{~d}$ \\
\hline T10 ZGB-703 & Low & High & No & Maluf et al. (2001) & $25.63 \mathrm{c}$ & $53.50 \mathrm{e}$ \\
\hline T11 ZGB-704 & Low & High & No & Maluf et al. (2001) & $23.33 \mathrm{c}$ & $54.42 \mathrm{e}$ \\
\hline T12 TOM-778 & High & High & No & Personal communication & $22.25 b$ & $44.00 \mathrm{~b}$ \\
\hline T13 TOM-780 & High & High & No & Personal communication & $20.50 b$ & $44.25 b$ \\
\hline T14 TOM-779 & High & High & No & Personal communication & $21.37 \mathrm{~b}$ & $43.67 b$ \\
\hline T15 P1-127826 & Low & Very High & No & Toscano et al. (2001) & $1.00 \mathrm{a}$ & $1.04 \mathrm{a}$ \\
\hline
\end{tabular}

(a) Lines homozygous for the described characteristics.

Means followed by the same letter in the columns belong to the same group according to the Scott-Knott test ( $\mathrm{p} \leq 0.05$ ).

Six days after infestation, oviposition was evaluated by counting the number of eggs in a $2 \mathrm{~cm}^{2}$ leaf area on four leaflets of the upper third of each plant with a binocular loupe with 20X to 80X magnification (Oksn 9585, Atibaia, São Paulo, Brazil). Twenty days after the infestation of sampled leaflets, previously marked with white tape, these were evaluated for the number of last instar nymphs with a binocular loupe. Mean temperature and RH between the infestation period and nymph count ranged from 11.2 to $20.3{ }^{\circ} \mathrm{C}$ and $52 \%$ to $100 \%$, respectively.

After verifying the normality and homogeneity of variance by the Shapiro-Wilk and Bartlett tests, respectively, data concerning the number of $B$. tabaci eggs and nymphs were transformed into $\left(\mathrm{x}+0.5^{1 / 2}\right)$ before performing ANOVA. Means were grouped by the Scott Knott test $(\mathrm{p} \leq 0.05)$ and contrasts selected from genotype clusters with different allelochemical contents and bearing the $M i$ gene, and were calculated with the Sisvar statistical software (Ferreira, 2011).

\section{RESULTS AND DISCUSSION}

According to the F-test, significant differences were observed between tomato genotypes that were tested for all evaluated traits (Table 1). Inbred lines with high AS or ZGB contents (T5 to T15) or only carrying the Mi gene (T5) showed less preference for both oviposition and reduced number of nymphs compared with the Santa Clara, TOM-695, TOM-556, and TOM-584 genotypes used as susceptible controls.

The Santa Clara, TOM-695, TOM-556, and TOM-584 genotypes were allocated in clusters with the highest oviposition and number of nymphs indicated by the Scott-Knott test (Table 1). These four genotypes are the most susceptible; they have in common the absence of the Mi-1 gene and lower contents of both allelochemicals. In contrast, inbred lines with high AS and/or ZGB contents (T6 to T15) as well as the inbred line with low allelochemical contents, but carrying the Mi-1 gene (T5), were less preferred for oviposition and reproduction when compared with the most susceptible controls (T1 to T4).

On the other hand, 'TOM-687' and 'TOM-688' that produced high AS contents, were allocated in clusters with significantly lower means than those of the T1 to T4 inbred lines (Tables 1 and 2, Contrast $\mathrm{C} 1$ ). These results prove the effectiveness of high foliar AS concentrations to produce resistance to whitefly, as previously described (Resende et al., 2009; Oliveira et al., 2012; Neiva et al., 2013). For 'TOM-687' and 'TOM-688', oviposition was reduced by $50.76 \%$ and $54.97 \%$ compared with 'Santa Clara', while the number of nymphs was reduced by $40.93 \%$ and $40.85 \%$, respectively.

Inbred lines with high ZGB, low AS content, and without the Mi gene (ZGB-703 and ZGB-704) also showed a significant level of antixenosis for oviposition and fewer whitefly nymphs when compared with the susceptible controls (Santa Clara, TOM-695, TOM-556, and TOM-584) (Tables 1 and 2, Contrast C2). The adverse effect of genotypes with high ZGB 
Table 2. Contrasts of interest estimates used to compare resistance to whitefly between genotypes and/or clusters of genotypes with different contents of acylsugar (AS) and zingiberene (ZGB) and resistance to nematodes.

\begin{tabular}{|c|c|c|c|c|}
\hline Id. & Contrast of interest & Description & $\begin{array}{l}\text { Number } \\
\text { of eggs } \\
\text { estimate }\end{array}$ & $\begin{array}{l}\text { Number } \\
\text { of nymphs } \\
\text { estimate }\end{array}$ \\
\hline $\mathrm{C} 1$ & {$[(\mathrm{~T} 1+\mathrm{T} 2+\mathrm{T} 3+\mathrm{T} 4) / 4-(\mathrm{T} 6+\mathrm{T} 7) / 2]$} & $\begin{array}{l}\text { Genotypes with low AS and ZGB and without } M i \text { gene vs. } \\
\text { genotypes with high AS, low ZGB, and without gene } M i\end{array}$ & $24.63 * *$ & $28.40 * *$ \\
\hline $\mathrm{C} 2$ & $[(\mathrm{~T} 1+\mathrm{T} 2+\mathrm{T} 3+\mathrm{T} 4) / 4-(\mathrm{T} 10+\mathrm{T} 11) / 2)]$ & $\begin{array}{l}\text { Genotypes with low AS and ZGB and without Mi gene vs. } \\
\text { genotypes with high ZGB and low AS }\end{array}$ & $29.89 * *$ & $30.15^{* *}$ \\
\hline $\mathrm{C} 3$ & {$[(\mathrm{~T} 1+\mathrm{T} 2+\mathrm{T} 3+\mathrm{T} 4) / 4-(\mathrm{T} 12+\mathrm{T} 13+\mathrm{T} 14) / 3]$} & $\begin{array}{l}\text { Genotypes with low AS and ZGB and without Mi gene vs. } \\
\text { genotypes with high AS and ZGB }\end{array}$ & $33.00 * *$ & $40.13 * *$ \\
\hline $\mathrm{C} 4$ & {$[(\mathrm{~T} 1+\mathrm{T} 2+\mathrm{T} 3+\mathrm{T} 4) / 4-(\mathrm{T} 5)]$} & $\begin{array}{l}\text { Genotypes with low AS and ZGB and without } M i \text { gene vs. } \\
\text { genotypes with low AS and ZGB with } M i \text { gene }\end{array}$ & $11.04 * *$ & $14.52 * *$ \\
\hline C5 & {$[(\mathrm{T} 1+\mathrm{T} 2+\mathrm{T} 3+\mathrm{T} 4) / 4-(\mathrm{T} 8+\mathrm{T} 9) / 2]$} & $\begin{array}{l}\text { Genotypes with low AS and ZGB and without } M i \text { gene vs. } \\
\text { genotypes with high AS and low ZGB and with } M i \text { gene }\end{array}$ & $23.96 * *$ & $26.62 * *$ \\
\hline C6 & {$[(\mathrm{T} 5)-(\mathrm{T} 6+\mathrm{T} 7) / 2]$} & $\begin{array}{l}\text { Genotypes with low AS and ZGB and with } M i \text { gene vs. } \\
\text { genotypes with high AS, low ZGB. and without } M i \text { gene }\end{array}$ & $13.58 * *$ & $13.88 * *$ \\
\hline C7 & {$[(\mathrm{T} 5)-(\mathrm{T} 10+\mathrm{T} 11) / 2]$} & $\begin{array}{l}\text { Genotypes with low AS and ZGB and with } M i \text { gene vs. } \\
\text { genotypes with low AS, high ZGB, and without } M i \text { gene }\end{array}$ & $18.85 * *$ & $15.62 * *$ \\
\hline C8 & {$[(\mathrm{T} 5)-(\mathrm{T} 12+\mathrm{T} 13+\mathrm{T} 14) / 3]$} & $\begin{array}{l}\text { Genotypes with low AS and ZGB and with } M i \text { gene vs. } \\
\text { genotypes with high AS, high ZGB, and without } M i \text { gene }\end{array}$ & $21.96 * *$ & $25.61 * *$ \\
\hline C9 & {$[(\mathrm{T} 5)-(\mathrm{T} 8+\mathrm{T} 9) / 2]$} & $\begin{array}{l}\text { Genotype with low AS and ZGB and with } M i \text { gene vs. } \\
\text { genotypes with high AS, low ZGB and with } M i \text { gene }\end{array}$ & $19.38^{* *}$ & $18.14 * *$ \\
\hline C10 & {$[(\mathrm{T} 6+\mathrm{T} 7) / 2-(\mathrm{T} 10+\mathrm{T} 11) / 2]$} & $\begin{array}{l}\text { Genotypes with high AS, low ZGB, without } M i \text { gene vs. } \\
\text { genotypes with low AS, high ZGB and without } M i \text { gene }\end{array}$ & $5.27 * *$ & $1.75^{\mathrm{ns}}$ \\
\hline C11 & {$[(\mathrm{T} 6+\mathrm{T} 7) / 2-(\mathrm{T} 12+\mathrm{T} 13+\mathrm{T} 14) / 3$} & $\begin{array}{l}\text { Genotypes with high AS, low ZGB, without } M i \text { gene vs. } \\
\text { genotypes with high AS, high ZGB and without } M i \text { gene }\end{array}$ & $8.38 * *$ & $11.74 * *$ \\
\hline $\mathrm{C} 12$ & {$[(\mathrm{~T} 6+\mathrm{T} 7) / 2-(\mathrm{T} 8+\mathrm{T} 9) / 2]$} & $\begin{array}{l}\text { Genotypes with high AS, low ZGB, without } M i \text { gene vs. } \\
\text { genotypes with high AS, low ZGB and with } M i \text { gene }\end{array}$ & $5.79 * *$ & $4.27 * *$ \\
\hline $\mathrm{C} 13$ & {$[(\mathrm{~T} 10+\mathrm{T} 11) / 2-(\mathrm{T} 12+\mathrm{T} 13+\mathrm{T} 14) / 3]$} & $\begin{array}{l}\text { Genotypes with low AS, high ZGB, without } M i \text { gene vs. } \\
\text { genotypes with high AS, high ZGB and without } M i \text { gene }\end{array}$ & $3.11 * *$ & $9.98 * *$ \\
\hline C14 & {$[(\mathrm{T} 10+\mathrm{T} 11) / 2-(\mathrm{T} 8+\mathrm{T} 9) / 2]$} & $\begin{array}{l}\text { Genotypes with low AS, high ZGB, without } M i \text { gene vs. } \\
\text { genotypes with high AS, low ZGB and with } M i \text { gene }\end{array}$ & $0.52^{\mathrm{ns}}$ & $2.52 * *$ \\
\hline
\end{tabular}

**, ${ }^{\text {ns }}$ Significant and nonsignificant at the 0.01 probability level, respectively, according to the F-test.

contents in the biological development of whitefly (B. tabaci biotype B) has been previously reported (Silva et al., 2009; Oliveira et al., 2012; Neiva et al., 2013). The presence of ZGB, although discrete, was significantly more effective than AS in reducing oviposition and number of nymphs (Contrast C10). For 'ZGB-703' and 'ZGB-704', oviposition was reduced by $59.39 \%$ and $63.04 \%$ as related to 'Santa Clara', while the number of nymphs was reduced by $43.24 \%$ and $42.26 \%$, respectively. Effects on whitefly survival provided by AS and ZGB, simultaneously present in the TOM-778, TOM-779, and TOM-780 inbred lines, were efficient to induce less preference to oviposition and fewer nymphs when compared with inbred lines with low content of these allelochemicals (Contrast C3); they were also more efficient than genotypes containing only one type of allelochemical such as high AS content (Contrast C11) or high ZGB content (Contrast C13).

The genotype carrying only the Mi gene (TOM-684) exhibited moderate resistance when compared with the susceptible controls (Table 2, Contrast C4). Genotypes with high AS contents and with the Mi gene (TOM-759 and TOM-760) had higher resistance to oviposition and fewer whitefly nymphs than the susceptible lines (Table 2, Contrast C5). There was a reduction of $46.42 \%, 44.42 \%$, and $26.18 \%$ in the number of nymphs per leaflet in lines carrying the $M i$ gene: TOM759 (AS + Mi gene), TOM-760 (AS + Mi gene), and TOM-684 (Mi gene), respectively. However, this resistance was lower than values reported by Nombela et al. (2003), who observed a reduction of $50 \%$ in the mean number of nymphs when compared with plants that did not carry the $M i$ resistance allele. Such differences may be justified by the relative magnitude influenced by temperature.

Inbred lines with high AS (TOM-687 and TOM-688), high ZGB content (ZGB-703 and ZGB-704), and high contents of both allelochemicals (TOM-778, TOM-779, and TOM-780) showed higher resistance to oviposition and lower number of whitefly nymphs compared with the genotype TOM-684, which carries the Mi gene (Table 2, Contrasts C6, C7, and C8). Therefore, the resistance level provided by $M i$ is lower than AS and ZGB separately or by AS and ZGB associated in the same genotype. Inbred lines with a high AS content and carrying the Mi gene (TOM-759 and TOM-760) were more 
resistant to oviposition and exhibited fewer nymphs than the line with only the $M i$ gene (TOM-684) (Tables 1 and 2, Contrast C9). On the other hand, 'TOM-759' and 'TOM-760' (high AS + Mi) were also more resistant to oviposition and exhibited fewer nymphs than 'TOM-687' and 'TOM-688', which only have high AS content (Table 2, Contrast C12).

Thus, the combined effect in oviposition due to the high AS content plus the presence of the Mi gene (high AS + Mi) is similar to the effect provided by high ZGB content. The effect of high AS + Mi as related to the number of nymphs is higher than the effect by ZGB (Table 2, Contrast 14).

The results obtained in the present study were similar to those reported by Nombela et al. (2003) and confirmed that the Mi-1 gene is involved in the partial resistance to B. tabaci biotype B in S. lycopersicum. Some studies also reported that $M i$ gene is efficient in controlling M. euphorbiae (Kaloshian et al., 1997; 2000; Goggin et al., 2001) and nematodes (Meloidogyne spp.) in tomato (Goggin et al., 2001; Mantelin et al., 2011; Atamian et al., 2012).

None of the genotypes were as resistant to whitefly as the wild accession PI-127826 (Table 1), indicating that the ZGB703 and ZGB-704 inbred lines, both derived from 'PI-127826', do not have all the genes responsible for resistance to whitefly. Therefore, these inbred lines had a resistance level similar to lines with high ZGB content, indicating that they have the same resistance mechanism.

In the present study, genotypes with high AS and ZGB contents had adverse effects on the biological development of B. tabaci biotype B. Similar results were found by Silva et al. (2009) and Neiva et al. (2013) for B. tabaci biotype B and for other pests such as Tuta absoluta and Myzus persicae (Oliveira et al., 2012; Silva et al., 2013).

Resistance levels to B. tabaci biotype B oviposition mediated by AS and ZGB in the same genotypes (TOM-778, TOM-779, and TOM-780) were significantly higher than in genotypes with only one allelochemical in their structure (Table 2, Contrasts C10, C11, and C13). Silva et al. (2009) found different results with respect to B. tabaci biotype B in which the double heterozygote genotypes had the same behavior as heterozygotes for ZGB or AS, and there was no synergistic effect of the simultaneous presence of ZGB and AS.

These results indicate that high AS and ZGB contents and the presence of the $M i$ gene are associated with higher resistance to whitefly in tomato. However, resistance levels provided by the presence of the $M i$ gene are lower than by high AS and/or ZGB contents. High ZGB content gives a similar resistance level for nymph survival in a high AS content, but it is slightly more effective than the latter in reducing oviposition.

Genotypes with high simultaneous AS $+M i$ were more resistant to whitefly than genotypes with only high AS or only the $M i$ gene. Genotypes with high AS + ZGB content exhibited a higher resistance level than genotypes with high AS or high ZGB content. It would seem that genotypes with the simultaneous presence of high AS and ZGB contents and with the $M i$ gene (high AS + high ZGB + Mi) could provide even higher resistance levels. To test this hypothesis, it is necessary to obtain a genotype that has the three traits, which is not available at the present time.

\section{CONCLUSIONS}

High foliar contents of allelochemicals such as acylsugar (AS) and zingiberene (ZGB) associated with the presence of the $M i$ gene in tomato plants may lead to higher resistance to whitefly. The resistance to whitefly mediated by the $M i$ gene is lower when compared with resistance levels mediated by AS and ZGB or simultaneously mediated by AS and ZGB. The combined effect of high AS content associated with the presence of the $M i$ gene is greater when compared with the effect of only high ZGB content on the resistance to whitefly.

\section{REFERENCES}

Andrade, M.C., Silva, A.A., Carvalho, R.C., Andrade, S.J., Oliveira, A.M.S., Francis, D.M., et al. 2018. Quantitative trait loci associated with trichomes in the Solanum galapagense accession LA1401. Genetic Resources and Crop Evolution 1-15. https://doi.org/10.1007/s10722-018-0644-3.

Andrade, M.C., Silva, A.A., Neiva, I.P., Oliveira, I.R., De Castro, E.M., et al. 2017. Inheritance of type IV glandular trichome density and its association with whitefly resistance from Solanum galapagense accession LA1401. Euphytica 213:1-12. https://doi.org/10.1007/s10681-016-1792-1.

Atamian, H.S., Eulgem, T., and Kaloshian, I. 2012. SIWRKY70 is required for Mi-1-mediated resistance to aphids and nematods in tomato. Planta 235:299-309. doi:10.1007/s00425-011-1509-6. 
Desneux, N., Luna, M.G., Guillemaud, T., and Urbaneja,A. 2011. The invasive South American tomato pinworm, Tuta absoluta, continues to spread in Afro-Eurasia and beyond: the new threat to tomato world production. Journal of Pest Science 84:403408. doi:10.1007/s10340-011-0398-6.

Ferreira, D. 2011. Sisvar: a computer statistical analysis system. Ciência e Agrotecnologia 35:1039-1042. http://dx.doi.org/10.1590/S1413-70542011000600001.

Freitas, J.A., Maluf, W.R., Cardoso, M.D., Gomes, L.A.A., and Bearzotti, E. 2002. Inheritance of foliar zingiberene contents and their relationship to trichome densities and whitefly resistance in tomatoes. Euphytica 127:275287. https://doi.org/10.1023/A:1020239512598.

Goggin, F.L., Williamson, V.M., and Ullman, D.E. 2001. Variability in the response of Macrosiphum euphorbiae and Myzus persicae (Hemiptera: Aphididae) to the tomato resistance gene Mi. Environmental Entomology 30:101-106. https://doi.org/10.1603/0046-225X-30.1.101.

Goncalves Neto, A.C., Silva, V.F., Maluf, W.R., Maciel, G.M., Nízio, D.A.C., Gomes L.A.A., et al. 2010. Resistência à traça-do-tomateiro em plantas com altos teores de acilaçúcares nas folhas. Horticultura Brasileira 28:203-208. http://dx.doi.org/10.1590/S0102-05362010000200011.

Inoue-Nagata, A.K., Lima, M.F., and Gilbertson, R.L. 2016. A review of geminivirus (begomovirus) diseases in vegetables and other crops in Brazil: Current status and approaches for management. Horticultura Brasileira 34:8-18. http://dx.doi.org/10.1590/S0102-053620160000100002.

Kaloshian, I., Kinsey, M.G., Ullman, D.E., and Williamson, V.M. 1997. The impact of Meu1-mediated resistance in tomato on longevity, fecundity and behavior of the potato aphid, Macrosiphum euphorbiae. Entomologia Experimentalis et Applicata 83:181-187. https://doi.org/10.1046/j.1570-7458.1997.00170.x.

Kaloshian, I., Kinsey, M.G., Williamson, M.V., and Ullman, E.D. 2000. Mi-mediated resistance against the potato aphid Macrosiphum euphorbiae (Hemiptera: Aphididae) limits sieve element ingestion. Environmental Entomology 29:609-695. https://doi.org/10.1603/0046-225X-29.4.690.

Kaloshian, I., Lange, W.H., and Williamson, V.M. 1995. An aphid-resistance locus is tightly linked to the nematoderesistance gene, $M i$, in tomato. Proceedings of the National Academy of Sciences of the United States of America 92:622-625. https://doi.org/10.1073/pnas.92.2.622.

Maluf, W.R.,Campos, G.A., and Cardoso,M.G. 2001. Relationships between trichome types and spider mite (Tetranychus evansi) repellence in tomatoes with respect to foliar zingiberene contents. Euphytica 121:73-80. doi:10.1023/A:1012067505361.

Maluf, W.R., Inoue, I.F., Ferreira, R.P.D., Gomes, L.A.A., Castro, E.M., and Cardoso, M.G. 2007. Higher glandular trichome density in tomato leaflets and repellence to spider mites. Pesquisa Agropecuária Brasileira 49:1227-1235. http://dx.doi.org/10.1590/S0100-204X2007000900003.

Maluf, W.R., Silva, V.F., Cardoso, M.G., Gonçalves Neto, A.C., Maciel, G.M., and Nízio, D.A.C. 2010. Resistance to the South American tomato pinworm Tuta absoluta in high acylsugar and/or high zingiberene tomato genotypes. Euphytica 176:113123. https://doi.org/10.1007/s10681-010-0234-8.

Mantelin, S., Peng, H.C., Li, B., Atamian, H.S., Takken, W.L.F., and Kaloshian, I. 2011. The receptor-like kinase SISERK1 is required for Mi-1-mediated resistance to potato aphids in tomato. Plant Journal 67:459-471. doi:10.1111/j.1365-313X.2011.04609.x.

Neiva, I.P., Andrade Júnior, V.C., Maluf, W.R., Oliveira,C.M., and Maciel, G.M.2013. Role of allelochemicals and trichome density in the resistance of tomato to whitefly. Ciência e Agrotecnologia 37:1. http://dx.doi.org/10.1590/S1413-70542013000100007.

Nizio, D.A.C., Maluf, W.R., Figueira, A.R., Nogueira, D.W., Silva, V.F., e Gonçalves Neto, A.C. 2008. Caracterização de genótipos de tomateiro resistentes a begomovírus por marcador molecular codominante ligado ao gene Ty-1. Pesquisa Agropecuária Brasileira 43:699-1705. http://dx.doi.org/10.1590/S0100-204X2008001200009.

Nombela, G., Williamson, V.M., and Muñiz, M. 2003. The root-knot nematode resistance gene Mi-1.2 of tomato is responsible for resistance against the whitefly Bemisia tabaci. Molecular Plant-Microbe Interactions 16:645-649. doi:10.1094/MPMI.2003.16.7.645.

Oliveira, C.M., Andrade Júnior, V.C., Maluf, W.R., Neiva, I.P., and Maciel, G.M. 2012. Resistance of tomato strains to the moth Tuta absoluta imparted by allelochemicals and trichome density. Ciência e Agrotecnologia 36:45-52. http://dx.doi.org/10.1590/S1413-70542012000100006.

Pereira, G.V.N., Maluf, W.R., Santos, C.D., Gonçalves, L.D., Nascimento, I.R., Gomes, L.A.A., et al. 2008. Seleção para alto teor de acilaçúcares em genótipos de tomateiro e sua relação com a resistência ao ácaro vermelho (Tetranychus evansi) e a traça (Tuta absoluta). Ciência e Agrotecnologia 32:996-1004. http://dx.doi.org/10.1590/S1413-70542008000300045.

Resende, J.T.V., Maluf, W.R., Cardoso, M.G., Gonçalves, L.D., Faria, M.V., and Nascimento, I.R. 2009. Resistance of tomato genotypes to the silverleaf whitefly mediated by acylsugars. Horticultura Brasileira 27:345-348. http://dx.doi.org/10.1590/S0102-05362009000300015.

Resende, J.T.V., Maluf, W.R., Faria, M.V., Pfann, A.Z., and Nascimento, I.R. 2006. Acylsugars in tomato leaflets confer resistance to the South American tomato pinworm, Tuta absoluta Meyr. Scientia Agricola 63:20-25. http://dx.doi.org/10.1590/S0103-90162006000100004. 
Rodríguez-Álvarez, C., Muñiz, M., and Nombela, G. 2017. Effect of plant development (age and size) on the $M i$ 1-mediated resistance of tomato to whitefly Bemisia tabaci. Bulletin of Entomological Research 107:768-776. doi:10.1017/S0007485317000281.

Rossi, M., Goggin, F.L., Milligan, S.B., Kaloshian, I., Ullman, D.E., and Williamson, V.M. 1998. The nematode resistance gene $\mathrm{Mi}$ of tomato confers resistance against the potato aphid. Proceedings of the National Academy of Sciences of the United States of America 95:9750-9754. https://doi.org/10.1073/pnas.95.17.9750.

Silva, A.A., Andrade, M.C., Maluf, W.R., Moraes, J.C., and Rezende, J.F. 2018. Resistance of tomato plant genotypes with high foliar allelochemical contents to the leafminer Liriomyza trifolii. Arquivos do Instituto Biológico 84:1-6. http://dx.doi.org/10.1590/1808-1657000892015.

Silva, V.F., Cardoso, M.G., Moraes, J.C., Pimentel, F.A., Gonçalves, L.D., e Neri, D.K.P. 2008. Caracterização e avaliação de acilaçúcar sintético no comportamento da mosca- branca Bemisia tabaci (Gennadius, 1886) biótipo B (Hemiptera: Aleyrodidae) em tomateiro. Ciência e Agrotecnologia 32:1408-1412.http://dx.doi.org/10.1590/S1413-70542008000500008

Silva, V.F., Maluf, W.R., Cardoso, M.G., Gonçalves Neto, A.C., Maciel, G.M., Nízio, D.A.C., et al. 2009. Resistência mediada por aleloquímicos de genótipos de tomateiro à mosca-branca e ao ácaro-rajado. Pesquisa Agropecuária Brasileira 44:12621269. http://dx.doi.org/10.1590/S0100-204X2009001000008.

Silva,A.A., Maluf,W.R., Moraes, J.C.,Alvarenga, R., e Costa,E.M.R. 2013. Resistência a Myzus persicae em genótipos de tomateiro com altos teores foliares de aleloquímicos. Bragantia 72:173-179. http://dx.doi.org/10.1590/S0006-87052013005000022.

Smith, P.G. 1994. Embryo culture of a tomato species hybrid. Proceedings of the American Society of Horticultural Science 44:413-416. doi:dx.doi.org/10.1590/S0102-05362002000400019.

Toloy, R.J., Mituti, T., Freitas, D.M.S., Maluta, N.K.P., Silva, T.N.Z., Lopes, J.R.S., et al. 2018. Features of the relationship between Tomato severe rugose begomovirus and Bemisa tabaci MEAM1 reveal that the virus is acquired during a probe lasting only one minute. European Journal of Plant Pathology 151:541-547. doi:10.1007/s10658-017-1388-1.

Toscano, L.C., Boiça Júnior, A.L., Santos, J.M., e Almeida, J.B.S.A. 2001. Tipos de tricomas em genótipos de Lycopersicon. Horticultura Brasileira 19:204-206. http://dx.doi.org/10.1590/S0102-05362001000300009.

Vosman, B., van't Westende, W.P.C., Henken, B., van Eekelen, H.D.L.M., Vos, R.C.H., and Voorrips, R.E. 2018. Broad spectrum insect resistance and metabolites in close relatives of the cultivated tomato. Euphytica 214:46. https://doi.org/10.1007/s10681-018-2124-4. 